\title{
Purification of Papain from Fresh Latex of Carica papaya
}

\author{
Rubens Monti ${ }^{1}$, Carmelita A. Basilio ${ }^{1}$, Henrique C. Trevisan ${ }^{2}$ and Jonas Contiero ${ }^{2}$ * \\ ${ }^{1}$ Departamento de Alimentos e Nutrição, Universidade Estadual Paulista, CEP 14801-902 Araraquara-SP, Brazil \\ ${ }^{2}$ Departamento de Bioquímica e Tecnologia Química, Universidade Estadual Paulista, CEP 14801-970 Araraquara \\ - SP, Brasil
}

\begin{abstract}
In the present study we wish to report a method of crystallizing papain from fresh papaya latex which gave higher yields than previously reported. This method does not involve the use of sulphydryl reagents. The papain thus obtained is practically pure and shows a single band when submitted to electrophoresis on polyacrylamide gel, and is identical to the papain obtained by other methods. In routine enzymatic assays, specific activity was measured using Z-gly-pNP and BAEE as substrates. Papain crystallized by this method, without the use of high concentrations of salts or thiol-containing substances such as cysteine and dithiothreitol, is obtained in the form of a complex with natural inhibitors existent in latex which can be removed by dialysis.
\end{abstract}

Key Word: papain; Carica papaya; cysteine proteinase; proteolytic enzymes; purification of papain

\section{INTRODUCTION}

The papain present in the latex of Carica papaya has been extensively studied (Brocklehurst et al., 1981, Brocklehurst et al., 1987, apud Thomas 1994, Mellor et al., 1993) and is an enzyme of industrial use and of high research interest. Among the major applications of papain are ts use in the food industry, (Neidlema, 1991) beer clarification, (Caygill, 1979) meat tenderizing, preparation of protein hydrolysates and others (Dupaigne, 1973). Balls et al., 1937, developed a process for the purification and isolation of papain in the native crystalline state from fresh latex. This method was later modified (Kimmel \& Smith, 1954) using commercially available dry latex and has been the classical method for papain preparation for many years, with some later modifications (Arnon, 1970, Baines \& Brocklehurst, 1979). According to Brocklehurst et al., 1981, Baines \& Brocklehurst, 1979, 1982, Brocklehurst et al., 1981, aqueous extracts of Carica papaya latex contain some cysteine proteinases that can be separated by ionexchange chromatography, and fully active forms can also be obtained by covalent chromatography using thiol-disulfide exchange (Brocklehurst et al., 1985, apud Mellor et al., 1993). The kinetics and ionization of the catalytic site of papain obtained by different methods (Cys-S- $/ \mathrm{His}^{-} \mathrm{Im}^{+} \mathrm{H}$ formation) are a matter of controversy. Studies carried out by one of the major groups specializing in research on the cysteine-proteinase family from the latex of Carica papaya have demonstrated the importance of the use of reversible inhibitors during their isolation and manipulation (Brocklehurst et al., 1981). The authors also emphasized that the multiple ionizations occurring in chymopapain and papain may be a general phenomenon for the cysteine-proteinase family (Thomas et al., 1994). In the present study we report on the development of a method for the purification and crystallization of native papain from fresh latex (Monti, 1983), which differs from the classical methods described in the literature. The method showed that papain precipitates spontaneously at low temperatures, presenting a high level of purity and excellent catalytic activity in comparison to classical methods of Kimmel \& Smith, 1954.

\footnotetext{
* Author for correspondence
} 


\section{MATERIALS AND METHODS}

Latex extraction. Fresh latex was obtained from developing green fruits directly picked from trees in the Araraquara region, State of São Paulo, Brazil. Three or four vertical incisions were made in the fruits with a sharp stainless steel instrument to a depth of 2 to $3 \mathrm{~mm}$. The latex that surfaces after incision lasts only 1 to 2 minutes and then rapidly coagulates and can be collected into a glass container. After extraction, the latex was immediately used for the purification of papain in its native state or stored at $-8{ }^{\circ} \mathrm{C}$ protected under a nitrogen atmosphere.

Isolation and crystallization of papain. The following procedure was used to obtain papain in crystalline form: 1) for extract preparation, ethylenediamine-tetraacetic acid (EDTA), $\mathrm{pH}$ 7.0, was added to the fresh latex to a final concentration of $1 \mathrm{mM}$ and the preparation was kept under nitrogen for $1 \mathrm{hr}$ at room temperature with constant shaking. Possible volatile dragged by nitrogen were qualitatively collected through bubbling distilled water and measured by absorbance in $230 \mathrm{~nm}$. The suspension was then centrifuged at $12,000 \mathrm{x} \mathrm{g}$ for $30 \mathrm{~min}$ at room temperature in a Sorvall RC-2B centrifuge with an SS-34 rotor. The supernatant (fraction 1) was opalescent and yellow-greenish in color and the precipitate, which consisted of insoluble material, was discarded. 2) The $\mathrm{pH}$ of fraction 1 was increased from 5.4 to 9.0 by slow addition of 0.1 $\mathrm{M}$ sodium hydroxide with constant agitation, and then centrifuged at $12,000 \mathrm{xg}$ for $10 \mathrm{~min}$ at room temperature. The clear supernatant (fraction 2) was placed in the first vessel connected with another through silicon hose. In the second flask were added $30 \mathrm{ml}$ of distilled water. By bubbling with nitrogen in the first flask and then passing through distilled water, an absorbance measure was read on a spectrophotometer (Ultrospec 1000 Pharmacia). The fraction 2 was placed in an ice bath and kept in an ice box. 3) After $72 \mathrm{hr}$ in an ice bath $\left(0{ }^{\circ} \mathrm{C}\right)$, papain precipitated spontaneously $(1 \mathrm{st}$ crystallization) and was collected by centrifugation at $12,000 \mathrm{x} \mathrm{g}$ for $20 \mathrm{~min}$ at $0{ }^{\circ} \mathrm{C}$ (fraction 3). 4) The fraction 3 was washed three times with a minimal necessary amount of $1 \mathrm{mM}$ EDTA, pH 7.0, at $4^{\circ} \mathrm{C}$. Then collected by centrifugation at $12,100 \mathrm{x} \mathrm{g}$ for $20 \mathrm{~min}$ at $0^{\circ} \mathrm{C}$ (fraction 4). 5) The fraction 4 was dissolved in a minimal necessary amount of $1 \mathrm{mM}$ EDTA, $\mathrm{pH}$ 7.0, at $37^{\circ} \mathrm{C}$ for $30 \mathrm{~min}$ at the proportion of $25 \mathrm{mg}$ protein $\mathrm{ml}^{-1}$ EDTA and then placed in an ice bath for spontaneous precipitation (1st recrystallization). The precipitate was dissolved in the minimal necessary amount of $1 \mathrm{mM}$ EDTA, $\mathrm{pH} 7.0$, and stored at $4{ }^{\circ} \mathrm{C}$ (fraction 5). The entire procedure was carried out under bubbling with nitrogen for protection against atmospheric oxygen. Protein was measured by the method of Itzhaki \& Gill (1964) and by absorbance at 280 nm.

Page. Non-denaturing electrophoresis was carried out by the method of Reisfield et al., 1962 for basic proteins, using $12 \%$ polyacrylamide gel, 34 $\mathrm{mM}$ B-alanine buffer, $\mathrm{pH} 4.3$, and a constant $4 \mathrm{~mA}$ current per tube. SDS-PAGE was carried out by the method of Laemmli, 1970 using 12\% acrylamide. The samples were prepared in Trisglicerol- $\beta$-mercaptoetanol and placed in a boiling water during $60 \mathrm{~s}$. Gels were stained with Coomassie-Blue R-250 and Brilliant Blue Gcolloidal concentrated by the method of Neuhoff, 1988.

Gel filtration of Sephadex G75. To determine the molecular weight of papain obtained by the method described in this paper, a column $(1.1 \mathrm{x}$ $100 \mathrm{~cm}$ ) of Sephadex G75 was used, previously equilibrated with a $0.1 \mathrm{M}$ sodium phosphate buffer, $1 \mathrm{mM}$ EDTA, $\mathrm{pH}$ 7.0. The following patterns were used: anidrase carbonic $(29 \mathrm{kDa})$, tripsinogen $(24 \mathrm{kDa})$, cytochrome $\mathrm{C}(12.4 \mathrm{kDa})$, lysozyme $(14.3 \mathrm{kDa})$ and classical papain obtained by Kimmel and Smith's method (1954). The exclusion volume $\left(\mathrm{v}_{0}\right)$ was determined with blue dextran.

Chromatography of fresh latex. Aliquots of proteins dissolved in $0.4 \mathrm{M}$ sodium acetate buffer, $\mathrm{pH} 5.0$, were applied to a CM-cellulose column $(1.5 \times 20 \mathrm{~cm})$ equilibrated with the same buffer. The material was eluted using a discontinuous gradient $(0.4$ to $1.0 \mathrm{M})$ of sodium acetate buffer, $\mathrm{pH}$ 5.0. The peaks obtained were delimited, pooled and dialyzed against $1 \mathrm{mM}$ EDTA at $4{ }^{\circ} \mathrm{C}$ with three successive changes of $10 \mathrm{hr}$ each. After dialysis, they were lyophilized and then submitted to electrophoresis on acid gels. 
Measurement of sulfhydryl groups. Sulfhydryl groups were determined by the method of Ellman. The reaction of papain with 5,5' - ditiobis - (2nitrobenzoic) (DTNB) was buffered with $0.1 \mathrm{M}$ sodium phosphate, $\mathrm{pH} 8.0$, and monitored spectrophotometrically at $412 \mathrm{~nm}, 25{ }^{\circ} \mathrm{C}$. The molar extinction coefficient of 13,600 was used for the DTNB reaction. When activated with DTE, papain samples were separated from the activator by gel filtration on Sephadex G-25 and were eluted with $0.1 \mathrm{M}$ sodium phosphate buffer, $\mathrm{pH}$ 8.0, and $1 \mathrm{mM}$ EDTA under a nitrogen atmosphere.

Enzymatic assays. Papain activity was determined with $\mathrm{N}$-carbobenzoxiglycil pnitrophenyl ester (Z-Gly-pNP) by the method of (Kirsch \& Igelströn, 1966). The reaction was monitored at $400 \mathrm{~nm}$ and $25{ }^{\circ} \mathrm{C}$ in $0.1 \mathrm{M}$ sodium phosphate buffer and $1 \mathrm{mM}$ EDTA, pH 7.0, plus $6.7 \%$ acetonitrile and ionic strength was adjusted to $0.3 \mathrm{M}$ with $\mathrm{KCl}$. Corrections for spontaneous hydrolysis were made. Specific activity is defined as $\mu$ mol of $p$-nitrophenol produced per min and per mg protein under the above conditions. The molar extinction coefficient of pnitrophenol was calculated as $9,368 \mathrm{M}^{-1} \mathrm{~cm}^{-1}$. Papain activity was also determined using $\alpha$-N-benzoyl-L-arginin ethyl ester (BAEE) as substrate (Davis \& Smith, 1955, Jacobsen et al., 1957). The rate of hydrolysis was measured by titration from the amount of base (1 M Tris) added to the unbuffered solution of enzyme and substrate in order to maintain a given $\mathrm{pH}$ value during the reaction. The reactions were carried out in a thermostatic cuvette at $25{ }^{\circ} \mathrm{C}$. A Beckman model SS-2 potentiometer sensitive to variations of 0.01 units in $\mathrm{pH}$ was used and Tris was added with a Nimetrics microsyringe capable of measuring amounts of up to $0.1 \mu$ l. The solution was thoroughly mixed by constant shaking and protected against atmospheric molecular oxygen by constant bubbling with nitrogen. The initial rate of reaction was calculated directly from the linear portion of the curves for substrate hydrolysis as a function of time and the catalytic constant for BAEE was determined by the ratio between maximum velocity and active enzyme concentration.

\section{RESULTS AND DISCUSSION}

Extraction of fresh latex. Maximum latex flow was obtained between 5:00 and 10:00 a.m. After latex extraction, fruits weighing 1 to $2 \mathrm{~kg}$ ripen and fruits weighing 200 to $300 \mathrm{~g}$ stop developing, many of them deteriorating. Medium-sized soil supply fruits weighing 0.5 to $1.0 \mathrm{~kg}$ are those containing the largest amounts of latex. A new latex extraction can be made 5 to 6 days later, but smaller amounts are obtained. We noted that for papaya trees growing on damp, the latex obtained was highly diluted with low papain concentrations. Using a total of 176 fruits we obtained $1524 \mathrm{~g}$ of latex, with a mean value of $9 \mathrm{~g}$ latex per fruit.

Papain crystallization, electrophoresis and gel filtration. When fresh latex is bubbled with nitrogen for $1 \mathrm{hr}$ at room temperature under constant shaking, a volatile substance is released which absorbs light at $250 \mathrm{~nm}$. When present in the latex extract (fraction 2) this substance prevents the spontaneous precipitation of part of the papain, that wasn't identifield (Monti, 1983). A total of $1396 \mathrm{mg}$ papain was obtained from 927 $\mathrm{g}$ fresh latex, with a value of $1.51 \mathrm{mg}$ papain per $\mathrm{g}$ latex. When fraction 2 was treated by bubbling with nitrogen, $1238 \mathrm{mg}$ papain was obtained from $510 \mathrm{~g}$ fresh latex, for a total of $2.43 \mathrm{mg}$ papain per $\mathrm{g}$ latex, with a consequent improvement in spontaneous papain crystallization. Electrophoresis of fresh latex on acid gel (fraction 2) revealed the presence of seven protein components migrating toward the cathode (Fig. 1, column 1, 4 and 6). Two proteins bands were detected in sample of fraction 4 (column 2 and 3) and electrophoresis of fraction 5 (column 5) showed a single protein band. This protein component had a relative mobility of $0.5 \pm 0.03$, corresponding to band 3 of the column 1, 4 and 6 and was identified as papain since papain prepared in our laboratory by the classical method (Kimmel \& Smith, 1954) has the same relative mobility. Gel electrophoresis denaturing of papain obtained by the method described here showed only one band (results not showed). The pure papain exhibited aparent molecular masses of $21 \mathrm{kDa}$ and the classical papain 21,3 kDa, when G75 Sephadex was used (Fig.2). Throught of methodology that we used in this work, was concluded that the papain prepared here have the same properties of 
the papain obtained from classical method.

Analysis of fresh latex. Chromatography on CMcellulose using a discontinuous sodium chloride gradient (Fig. 3) yielded a reproducible

pattern of protein elution (Basílio, 1987). The chromatography of fresh latex revealed the presence of 5 protein components. Since in an identical experiment (Schack, 1967) peak 2 was characterized as papain, the fraction corresponding to peak 2 in Fig. 3 was pooled, concentrated with ammonium sulfate $(600 \mathrm{~g} / \mathrm{l})$,

dialyzed and submitted to electrophoresis of acid gel, revealing a single protein band with the same mobility as band 3 on the total latex gel (Fig. 1, column 1). An additional electrophoretic run was then carried out on acid gel using a mixture of peak 2 with the protease extracted by

the method described in the present paper (Fig. 4, gel 1) and a mixture of peak 2 with papain extracted by the classical method (Fig. 4, gel 2). Thus, we conclude that the protease obtained by the method described here is provenly the papain and the methodology here described adds to the ones already in use.

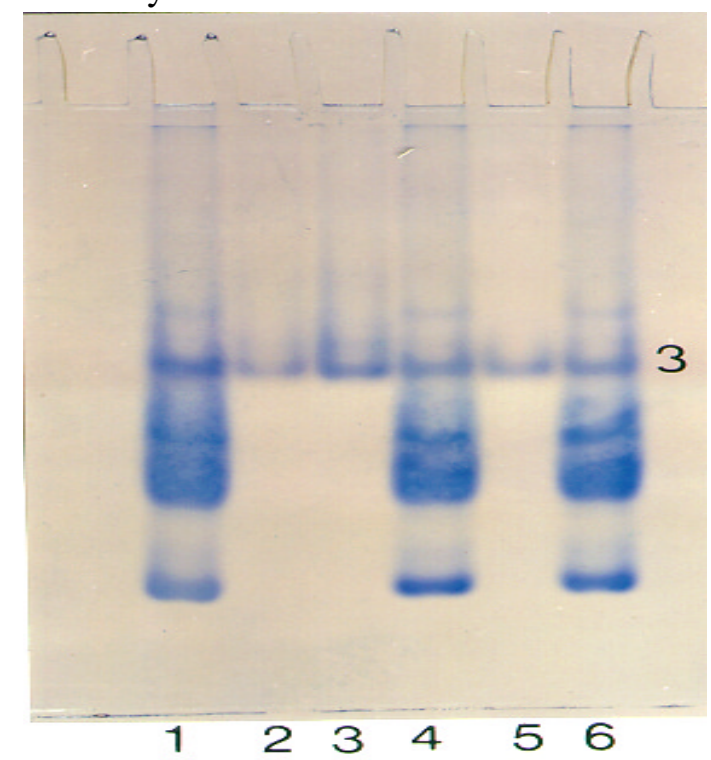

Figure 1 - Nondenaturing polyacrylamide gel electrophoresis using $12 \%$ acrylamide gel in the $\beta$ alanine acetic acid buffer at $\mathrm{pH}$ 4.3. Staining was by Brilliant Blue G-colloidal. In the columns 1, 4 and 6 , were added aliquot of the fraction 2 (crude latex). In the column 2 and 3, aliquot of fraction 4 . In the column 5, aliquot of fraction 5 (recrystalization). The purity of the band 3 was confirmed electrophoresis and immunologic assay (Basílio, 1993).

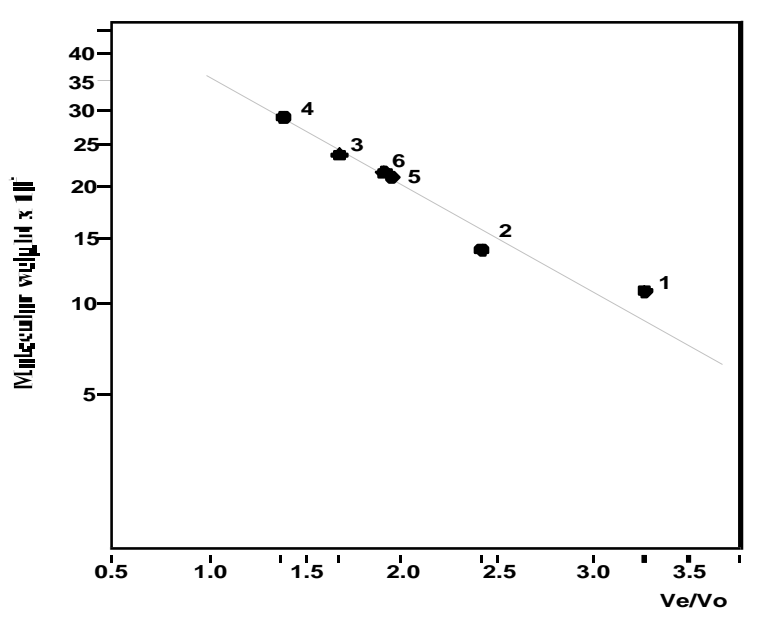

Figure 2 - Molecular weight estimation of papain by Sephadex G - 75 gel filtration colunm $(1.1$ x $100 \mathrm{~cm})$, equilibrated with $0,1 \mathrm{M}$ sodiun phosphate buffer , EDTA $1 \mathrm{mM}, \mathrm{pH} 7,0$, flow rate $20 \mathrm{~mL} /$ hour at room temperature. 1) Cytochrome $\underline{\mathbf{c}}$; 2) Lysozym; 3) Tripsinogen; 4) Carbonic Anhydrase; 5) Papain from Kimmel \& Smith, 1954; 6) Papain from our methodology

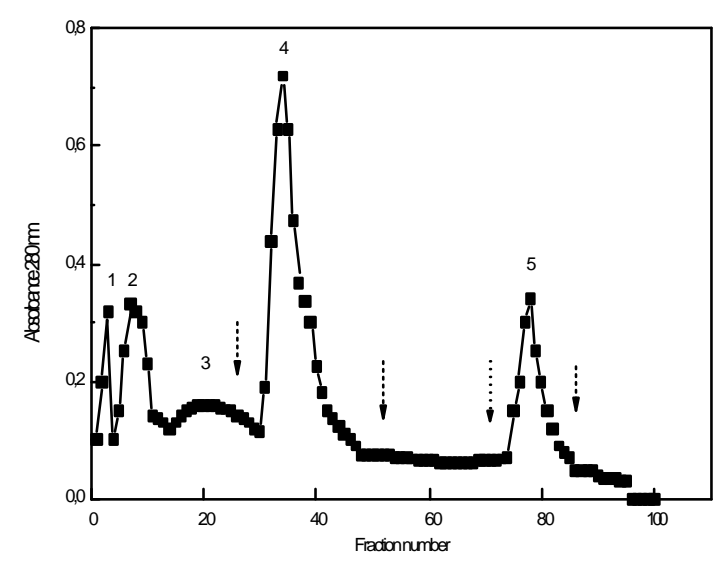

Figure 3 - CM-cellulose Chromatography of crude latex of the Carica papaya. The column $(1,5 \times 20 \mathrm{~cm})$ after equilibrated with $0.4 \mathrm{M}$ sodium acetate buffer, $\mathrm{pH}$ 5.0 , was added $60 \mathrm{mg}$ of the protein, and eluted with $0.4,0.6,0.8$ and $1.0 \mathrm{M}$ with the same buffer at a flow rate of $30 \mathrm{~mL} / \mathrm{h}$. Fraction of $9 \mathrm{~mL}$ were collected. 


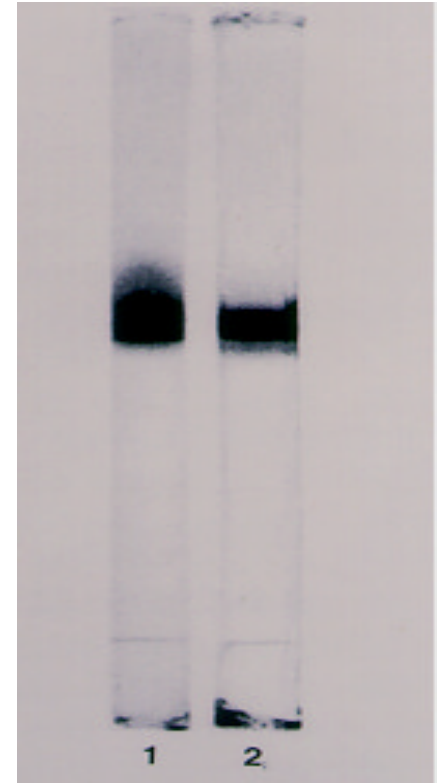

Figure 4 - Non-denaturing polyacrylamide gel electrophoresis using $12 \%$ acrylamide gel and $ß$-alanine buffer, $\mathrm{pH}$ 4.3. Staining was by Coomassie Blue R250. Gel 1 - Mixture of peak 2 with classic papain. Gel 2 Mixture of peak 2 with the papain extracted by this method.

Number of sulfhydryl groups per mol papain. The number of free sulfhydryl groups in the papain prepared by the method described here was determined with 5,5'-dithiobis-(2-nitrobenzoic) acid (DTNB). Different numbers of sulfhydryl groups have been reported in the literature. Finkle \& Smith, 1958, Glazer \& Smith, 1965 determined to the papain by classical method $0.5 \mathrm{~mol} \mathrm{SH}$ per mol papain. Surprisingly, the number of sulfhydryl groups in papain obtained by the present method was $1.5 \mathrm{~mol} \mathrm{SH}$ per mol papain. However, freshly prepared papain filtered through Sephadex G-25 or activated with dithioerythritol (DTE) and then filtered presented a mean value of $0.76 \mathrm{~mol} \mathrm{SH}$ per mol papain, result also obtained for Jorge, 1977, showing, this way, the liberation of some reducible substances. The enzyme dialysed twice against distilled water presented a slightly lower value due to the oxidation of sulfhydryl groups. The mean value detected for the dialysed enzyme was 0.62 SH per mol enzyme, being detected the liberation of the natural inhibitory of papain during the purification process.

Assay of enzyme activity. Daily kinetic studies of papain were performed using carbobenzoxyglycyl p-nitrophenyl ester ( Z-Gly-pNP ) as substrate because of the rapid and easy preparation, the possibility of working under conditions of saturation with the substrate and finally because of the small amounts of enzyme (approximately 20 $\mu \mathrm{g}$ ) needed for an assay. We carried out a systematic study of the kinetics of papain because we had modified the method for purification and also because the prepared papain presented a hight value of SH per mol enzyme. Table 1 shows the results obtained with three different preparations. We determined the activity of freshly prepared papain without treatment, of freshly prepared papain filtered through Sephadex G-25, and of freshly prepared papain activated with DTE and then filtered through Sephadex G-25. Assuming that the number of SH groups of untreated papain $(0.76)$ is equal to the number detected in the enzyme filtered through Sephadex G-25, it can be seen that the Kcat.s ${ }^{-1}(\mathrm{~mol} \mathrm{SH})^{-1}$ was not modified when compared to the value obtained for papain filtered through Sephadex G-25. However, treatment with DTE did not lead to a great increase in Kcat.s ${ }^{-1}(\mathrm{~mol} \mathrm{SH})^{-1}$. The most probable hypothesis to explain these results may be the presence of natural inhibitors forming a complex with the enzyme prepared by this method and released from the enzyme during DTE treatment and filtration. On the basis of these esults, we carried out an experiment in which catalytic activity was measured at different enzyme concentrations (Table 2). A $55 \%$ increase in Kcat. ${ }^{-1}(\mathrm{~mol} \mathrm{SH})^{-1}$ was observed when the enzyme concentration was decreased, demonstrating once again the presence of an inhibitory substance. Enzymatic assays were also carried out using the synthetic substrate $\alpha$-N-benzoyl-L-arginine ethyl ester (BAEE) as described by Davis \& Smith, 1955 and modified by Jacobsen et al., 1957. Papain prepared by the present method was used for these assays and the enzyme was always treated with DTE for reduction of sulfhydryl groups and filtered through Sephadex G-25. Table 3 summarises the results obtained for four different preparations. In brief, the enzyme papain prepared by the method described in this work is the same the enzyme obtained by the classic method, with the advantage of not receiving treatment for salts in high concentrations (or thiolcontaining substances ), providing like this, papain with minimum alterations in its kinetic properties. This preparation method allowed to detect the presence of inhibitor substances forming a 
complex with the papain. They were isolated and separated by chromatography in SP Sephadex C25 three inhibitor substances, of small molecular masses, and the results will be presented later on. A possible hypothesis is that the complex formation with one of these inhibitors can induce alterations in the results of the catalytic constant and number of sulfhydryl groups per mol papain.

Table 1 - Esterase activity of papain at different treatments

\begin{tabular}{|c|c|c|c|}
\hline \multirow[t]{2}{*}{ Preparation } & Treatment & \multirow{2}{*}{$\frac{\text { Kcat.s }^{-1}}{\text { mol protein }}$} & \multirow{2}{*}{$\begin{array}{l}\text { Kcat.s }{ }^{-1} \\
\text { mol SH }\end{array}$} \\
\hline & & & \\
\hline \multirow{4}{*}{1} & None & 6.00 & 7.90 \\
\hline & G-25 & 5.74 & 7.55 \\
\hline & DTE & 7.85 & 10.30 \\
\hline & G-25 & & \\
\hline \multirow{4}{*}{2} & None & 3.90 & 5.20 \\
\hline & G-25 & 4.00 & 5.33 \\
\hline & DTE & 7.30 & 9.73 \\
\hline & G-25 & & \\
\hline \multirow{3}{*}{3} & None & 5.20 & 6.50 \\
\hline & G-25 & 5.00 & 6.25 \\
\hline & $\begin{array}{l}\text { DTE } \\
\text { G-25 }\end{array}$ & 7.71 & 9.64 \\
\hline
\end{tabular}

The following conditions were used: kcat was

determined using the substrate Z-Gly-pNP $2 \times 10^{-4} \mathrm{M}$, enzyme concentration of $2 \times 10^{-8} \mathrm{M}$ in $0.1 \mathrm{M}$ sodium phosphate buffer and $1 \mathrm{mM}$ EDTA, $\mathrm{pH} 7.0$; ionic strength 0.3 , and acetonitrile $6.7 \%$; temperature, $25^{\circ} \mathrm{C}$.

Table 2 - Esterase activity measured at different papain concentrations

\begin{tabular}{|c|c|c|}
\hline \multirow{2}{*}{$\begin{array}{c}\text { Enzyme } \\
\text { concentration in } \\
\text { the reaction }\end{array}$} & Kcat.s ${ }^{-1}$ & Kcat.s ${ }^{-1}$ \\
\hline & mol protein & $\mathrm{mol} \mathrm{SH}$ \\
\hline $2.30 \times 10^{-8} \mathrm{M}$ & 3.10 & 4.08 \\
\hline $1.74 \times 10^{-8} \mathrm{M}$ & 3.40 & 4.48 \\
\hline $1.17 \times 10^{-8} \mathrm{M}$ & 4.00 & 5.28 \\
\hline $5.92 \times 10^{-9} \mathrm{M}$ & 4.80 & 6.32 \\
\hline $\begin{array}{l}\text { The following co } \\
\text { determined using } 2 \\
\text { in } 0.1 \mathrm{M} \text { sodium } \mathrm{p} \\
\mathrm{pH} 7.0 ; \text { ionic stre } \\
\text { temperature, } 25^{\circ} \mathrm{C}\end{array}$ & $\begin{array}{l}\text { itions were } \\
10^{-4} \mathrm{M} \text { Z-Gly }\end{array}$ & $\begin{array}{l}\text { kcat was } \\
\text { as substrate, } \\
\mathrm{mM} \text { EDTA, } \\
\text { onitrile } 6.7 \% \text {; }\end{array}$ \\
\hline
\end{tabular}

Table 3 - Determination of Km, Vmax and Kcat using BAEE as substrate

\begin{tabular}{cccc}
\hline $\begin{array}{c}\text { Preparati } \\
\text { on }\end{array}$ & $\begin{array}{c}\mathrm{Km} \\
(\mu \mathrm{M})\end{array}$ & $\mathrm{V}_{\max }\left(\mu \mathrm{mols.L^{-1 }} \cdot \mathrm{s}^{-1}\right)$ & Kcat.s $^{-1}$ \\
\cline { 4 - 4 } & & $\mathrm{mol} \mathrm{SH}$ \\
\hline 1 & 17.9 & 22.20 & 28.5 \\
3 & 20.6 & 20.40 & 28.0 \\
4 & 20.0 & 22.70 & 28.1 \\
\hline
\end{tabular}

The following conditions were used: BAEE in $0.3 \mathrm{M}$ $\mathrm{KCl}, \mathrm{pH}$ maintained at 6.0 with $1.0 \mathrm{M}$ Tris at $25^{\circ} \mathrm{C}$. Enzymatic concentration from 1 to $2 \times 10^{-6} \mathrm{M}$, activated with DTE and filtered through Sephadex G25.

\section{ACKNOWLEDGEMENTS}

We are indebted to Prof. João Atílio Jorge for suggestions. This work is part of two Master's Dissertation submitted by R. M. and C. A. B. to Department of Biochemistry of the School of Medicine of Ribeirão Preto (University of São Paulo).

\section{RESUMO}

No presente trabalho apresenta - se um método de cristalização da papaína oriunda do látex fresco de mamão, o qual apresenta uma alta produtividade em relação aos métodos previamente descritos. A metodologia aqui descrita não envolve o uso de reagentes sulfidrílicos, a papaína foi obtida de forma praticamente pura, apresentando uma simples banda quando submetida a eletroforese, e com propriedades idênticas àquelas obtidas por outros métodos. A atividade específica foi determinada utilizando Zgly-pNP e BAEE como substrato. A papaína obtida por essa metodologia, sem uso de substâncias tais como cisteína e ditiotreitol, apresenta - se na forma de um complexo com inibidores naturais, os quais podem ser removidos por diálise.

\section{REFERENCES}

Arnon, R. Papain. Methods Enzymol., v.19,p.226 - 44, 1970.

Baines, B.S.; Brocklehurst, K. A necessary modification to the preparation of papain from any high - quality latex of Carica papaya and evidence for the structural integrity of the enzyme produced by 
traditional methods. Biochem. J. , v. 177, p. $541-48$, 1979.

Baines, B.S.; Brocklehurst, K. Isolation and characterization of the four major cysteine proteinase component of the latex of Carica papaya L. Reactivity characteristics towards 2, 2' - dipyridyl disulfide of the thiol groups of papain, chymopapains A e B, and papaya peptidase A. J. Protein Chem. , v.1, p. 119 - 39, 1982.

Balls, A.K..; Lineweaver, H.; Thompson, R.R. Isolation and properties of cristalin papain. Science, v. 86, p. 379 - 81, 1937.

Basilio, A. C. Estudo calorimétricos, cinéticos, e imobilização das enzimas proteolíticas presentes no látex de Carica papaya(mamoeiro)- Campinas, 1993, 156 p. Tese (Doutorado) Instituto de Química, Universidade Estadual de Campinas.

Basilio, A.C. purificação da quimopapaina B e de um inibidor de pequeno peso molecular no latex de Carica papaya (Mamoeiro). Ribeirão Preto, 1987. 129 p. Tese (Mestrado) - Faculdade de medicina de Ribeirão Preto, Universidade de São Paulo.

Brocklehurst, K.; Baines, B. S.; Kierstan, M. P. J. Papain and other constituintes of Carica papaya $\mathrm{L}$. Top. Enzyme Ferment. Biotechnol. , v. 5, p. 262 - 35, 1981.

Caygill, J.C. Sulfhydryl plant proteases. Enzyme and Microb. Technology , v.1, p. $233-42,1979$.

Davis, C.N.; Smith, E. Kinetics of papain - catalyzed hidrolysis of $\alpha-N$ - Benzoyl - L - arginine Ethyl Ester. Methods Biochem. Anal., v. 2, p. 25 - 18, 1955.

Dupaigne, P. Some industrial aplications of fruit components. Fruits, v. 28, p. 305 - 18, 1973.

Ellman, G.I. Tissue sulfihydryl group. Arch. Biochem. Biophys., v. 82, p. 70 - 7, 1959.

Finkle, B.J.; Smith, E.L. J. Crystalline papain; number and reactivity of thiol groups; chromatografic behavior. J. Biol. Chem. ,v. 230, p. 669 -90, 1958.

Glazer, A.N.; Smith, E.L. The sulfur distribuition of papain. J. Biol. Chem. , v. 240, p. 201 - 7, 1965.

Itzhaki, R.F.; Gill, D.M. A microbiuret method for estimating proteins. Anal. Biochem. , v. 9, p. 401 - 4, 1964.

Jacobsen, C.F.; et al. The pH-stat and its use in biochemistry. Methods of Biochem. Anal. , v. 4, p. $171-210,1957$.

Jorge, J. A. Caracterização parcial das proteinas do látex de Carica papaya, com especial referência a purificação e caracterização cinética da papaina do látex fresco. Ribeirão Preto, 1977, 104 p. Tese
(Mestrado) - Faculdade de Medicina de Ribeirão Preto, Universidade de São Paulo.

Kimmel, J.R.; Smith, E.L. Crystalline papain. I. Preparation, specificity, and activation. J. Biol. Chem. , v. 207, p. 515 - 30, 1954.

Kirsch, J.R.; Igelströn, M. The kinetics of the papain catalyzed hydrolisis of esters of carbobenzoxyglycine. Evidence for an Acyl - enzyme intermediate. Biochemistry, v. 5, p. 783 - 91, 1966.

Laemmli, U.K. Clevation of structural proteins during the assembly of the rhead of bacteriophage T4. Nature, v. 227, p. $680-85,1970$.

Mellor, G. W. et al. Ionization characteristics of the Cys - 25/His - 159 interactive system and of the modulatory group of papain: resolution of ambiguity by electronic perturbation of the quasi - 2 mercaptopyridine leaving group in a new pyrimidyl disulphide reactivity probe. Biochem. J. , v. 290, p. 289 - 96, 1993.

Monti, R. purificação parcial de inibidores da papaina presentes no 1 tex de Carica papaya. Ribeirão Preto, 1983. 101 p. Tese (Mestrado) - Faculdade de Medicina de Ribeirão Preto, Universidade de São Paulo.

Neidlema, S.L. Enzymes in the food industry a backward glance. Food Technology, v. 45, p. 88 - 91, 1991.

Neuhoff, V.; Stamm, R.; Eibl, H. Electrophoresis, v. 9, p. 255-56, 1988.

Reisfeld, R.A.; Lewis, V.J. , Willians, D.E. Disk electrophoresis of basic proteins and peptides on polyacrylamide gels. Nature, v. 195, p. 281 - , 1962.

Schack, P. Fractionation of proteolytic enzyme of dried papaya latex. Isolation and preliminary characterization of a new proteolytic enzyme. Compt. Rend. Trav. Lab. Carlsberg, v. 36, p. 67 - 83, 1967.

Thomas, M.P. et al. Structure of chymopapain M the late - eluted chymopapain deduced by comparative modelling techniques and active - centre characteristics determined by $\mathrm{pH}$ - dependent kinetics of catalysis and reactions with time - dependent inibitors: the Cys - 25/His - 159 ion - pair is insufficient for catalytic competence in both chymopapain $\mathrm{M}$ and papain. Biochem.J., v. 300, p. 805 - 20, 1994.
Received: June 23, 1999; Revised: July 29, 1999; Accepted: May 08, 2000. 